\title{
Un Poeta Romántico Chileno
}

\author{
A Pedro Grases
}

A obra literaria de Guillermo Blest Gana se compone de poesías
líricas, drama en verso y prosa periodística. El estudio de esta
última porción de su labor se hace difícil, porque no ha sido seleccio-
nada en volumen.

Las poesías líricas y dramáticas han sido publicadas (1907-1909) en tres grandes volúmenes con el título de Obras completas. Los dos primeros llevan prólogo de Antonio Orrego Barros.

Por ahora me voy a ocupar sólo del lirismo del romántico chileno. Aparece en la escena publicitaria a mediados del siglo xix. En 1854 da a la prensa su primer libro, Poesías. ${ }^{1}$ "No podría afirmar - dice el docto catedrático Enrique Nercasseau y Morán- si ésta es la primera publicación en Chile de un libro de poesías de un solo y mismo autor; pero lo que sé decir, sin agravio de muertos ni de vivos, es que hasta entonces no había aparecido en Chile un libro de ese género y de igual importancia." ${ }^{2}$

En esta primera obra el poeta se presenta, sin dominar la técnica literaria. Pero en sus poemas se siente al lírico legítimo, al cantor auténtico. Sin embargo, la voz de algunos maestros de la escuela romántica: Musset, Espronceda, se deja entreoír en los versos del chileno.

Es la etapa del aprendizaje, etapa de asimilación y entusiasmo en que no se alcanza a levantar la voz propia. Pero el autor de méritos, con el tiempo, se independiza y sabe encontrar la verdadera senda de su personalidad artística.

El primer libro de Blest Gana, si no lo honra, es el paso prepara. torio para su producción original. No obstante sus deficiencias, es preciso señalar algunas de sus composiciones de esta primera jornada: "El junco y el ciprés", "Poesía", "Soneto". En éstas el poeta consigue traducir una emoción personal y perdurable. 
El tono del libro se mantiene en el canon romántico. No es todavía un creador. No obstante, el acento peculiar logra plasmarse en versos claros y sencillos. El misterio de la acción creadora, empero, no se le escapa. Es así como en su poena titulado "Poesía", canta:

Hay una poesía dulce, tierna, melancólica, vaga y misteriosa que nadie ha escrito, y que tal vez ninguno podrá jamás copiar en sus estrofas.

El cuarteto anterior resulta ilustrativo no sólo por su concepto de la poesía, sino por el elemento idiomático. En efecto, es en este último aspecto en el cual se puede apreciar mejor la etapa de aprendizaje del joven poeta. E1 verbo "copiar" es de una inexactitud chocante. Pues el poeta no "copia". Expresa. La función poética, esto es, creadora, consiste en expresar la emoción íntima o el objetivo acontecimiento que palpita en el artista del verbo.

Pero, en cambio, el sentido profundo del poeta se traduce en el cuarteto citado. Su actitud es humilde. Conoce por intuición la pequenez de su poder y lo confiesa con modestia sencilla y sincera. La poesía es magia verbal que sólo los elegidos pueden hallar. $\mathrm{Y}$, sin embargo, lo poesía no es solamente cuestión de idioma. Es algo más...

El soneto que principia "Si a veces silencioso y pensativo", de Poesías, es, sin duda, el primero de tal tipo. Es composición lograda. $\mathrm{El}$ autor sabe acomodar su sentimiento poético a esta composición con rara eficacia estética. De ahí que sus sonetos, la mayoría, posean sutil belleza. "Me dió - le habla a Orrego Barros- por hacer sonetos, porque encuentro que es el molde más adecuado para encuadrar un pensamiento"... ${ }^{3}$

Antonio Orrego Barros reúne en el primer tomo de las Obras completas, además de Poesías, "La flor de la soledad", dada a la estampa en $1857 .{ }^{4}$

Tal poema es una leyenda - dividida en doce partes- que, sin apartarse de la índole romántica, posee cierto objetivismo descriptivo interesante, no tanto por su desarrollo cuanto por el tono distinto al resto de la obra de Blest Gana. Palpita en más de una de sus secciones un humorismo algo inglés:

Yo no soy de esos Byron de quince años que, salidos ayer de las escuelas, hablan ya de dolor y desengaños: dolores puede ser, pero de muelas; 


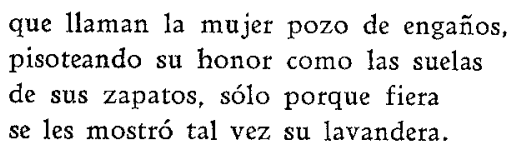

En 1884 publica Armonías. ${ }^{5}$ En este libro alquitara su estilo y consigue verdaderos aciertos en el soneto. En efecto, en el citado volumen se pueden leer: "Mirada retrospectiva", el soneto que comienza "Los años pasarán, y acaso un día", "Sombras", "Adán y Eva", "E1 primer beso", para no citar sino unos cuantos poemas de valor perdurable.

Guillermo Blest Gana es un buen poeta romántico nacional. Sin embargo, su concepto de la poesía no es brillante ni profundo. "Los versos - le dice a Orrego Barros- deben ser suaves y armoniosos y ... con un poquito de poesía o sentimiento, que es lo mismo." "La única poesía - agrega- que puede vivir y que Ud. debe hacer, si quiere que sus versos no duren lo que las rosas de verano, es bella poesía, poesía suave, verdadera y sobre todo con mucho sentimiento." 6 Para el autor de "La conjuración de Almagro", la poesía debe ser belleza y sentimiento. ¿Y la expresión y el estilo? No le preocupan. Son detalles, puesto que ni menciona elementos de tanta importancia para el arte poético. ¿Limitación? No cabe duda. El hombre es limitado por naturaleza.

El compilador de las Obras completas -que no son completas, pues no contienen la prosa del poeta- colecciona en el segundo volumen: Sonetos y fragmentos y Hojas al viento. Estas poesías se publicaron en periódicos y revistas de la época. Pues bien, en Sonetos y fragmentos figuran: "A la muerte", "Ayer y hoy" y "Lo único eterno", sonetos dignos de la antología más estricta. Blest Gana, aunque no hubiera escrito más poesías que éstas y los sonetos antes mencionados, ocuparía un sitio honroso en cualquier buen florilegio de la lengua española.

En 1863 es nombrado miembro de la Facultad de Filosofía y Humanidades de la Universidad de Chile. Al ingresar pronuncia, como es de rigor, un discurso de incorporación. Hace, en esa oportunidad, consideraciones sobre la poesía lírica y sus tendencias en Hispanoamérica. Al terminar, dice: "Lo que nos falta para producir obras dignas de memoria, es el estudio, la constancia y el trabajo." 7 ¿Cuánta verdad expresa el poeta! Es necesario tener en cuenta tal lección. 
La poesía romántica chilena, en general, no tiene calidad literaria. No plasma la vivencia profunda del poeta, sino que modula un canto a la moda de ese tiempo. Sus principales representantes: Salvador Sanfuentes, Hermógenes de Irisarri, Eusebio Lillo, Guillermo Matta, Adolfo Valderrama, Luis Rodríguez Velasco, Zorobabel Rodríguez, Carlos Walker Martínez, José Antonio Soffia, Enrique del Solar, no tienen sino momentos contados de feliz expresión poética. Sin embargo, son los iniciadores de una poesía nacional, poesía que con el renovar del calendario ha conseguido una bella madurez lírica y un auténtico sentido estético.

El romanticismo del autor de Armonías, sin ser notable, es original en la última etapa de su plasmación. Posee elementos humorísticos de buen tono, elementos que son el anuncio de la modalidad post-romántica chilena, y cuyo representante más alto es Eduardo de la Barra.

En el soneto "Ayer y hoy", dice Blest Gana:

La edad de los románticos cantores tuvo ridiculeces, no lo niego, pero veo con pena extinto el fuego, desierto el templo y el altar sin flores.

Un poeta que ve el defecto de su escuela, está en condiciones de cambiar. Blest Gana no cambia; pero abre la brecha de la duda. Y esta conducta poética debe ser señalada como un indicio promisor.

De los románticos nacionales, sin duda, el autor de Poesías es quien mejor maneja la materia lírica y quien más bellos poemas deja a las nuevas generaciones.

Norberto Pinilla, Santiago de Chile.

\section{NOTAS} 1863.

1 Santiago de Chile. Imprenta Chilena. Segunda edición. París. Laplace,

2 Sobre la poesia en general, y en especial sobre las de don Guillermo Blest Gana. Anales de la Universidad de Chile. Santiago. IX-X. 1906.

3 Obras completas, vol. I, p. XI.

4 Santiago. Imprenta del País.

5 Santiago. Rafael Jover, editor.

6 Obras completas, vol. I, p. XIII.

7 La cita es de Nercausseau y Morán. Ib. 